Article

\title{
Serological Survey of Ehrlichia canis and Anaplasma phagocytophilum in Dogs from Central Italy: An Update (2013-2017)
}

\author{
Valentina Virginia Ebani \\ Department of Veterinary Science, University of Pisa, viale delle Piagge 2, 56124 Pisa, Italy; \\ valentina.virginia.ebani@unipi.it
}

Received: 19 November 2018; Accepted: 31 December 2018; Published: 4 January 2019

\begin{abstract}
Ehrlichia canis and Anaplasma phagocytophilum are tick-borne bacteria of veterinary concern. Indirect immunofluorescent assay was carried out to detect antibodies against E. canis and A. phagocytophilum in 1026 owned dogs living in Central Italy during the period 2013-2017. One hundred and eighty-six (18.12\%) dogs were positive for at least one pathogen and $14(1.36 \%)$ for both agents. More in detail, 166 (16.18\%) samples were positive for E. canis and 34 (3.31\%) for A. phagocytophilum. No statistically significant differences in the seroprevalence values related to gender were detected, whereas the highest rate to E. canis occurred in animals aged more than 10 years. Mean seroprevalence values for both E. canis and A. phagocytophilum detected in 2014 and 2015 were statistically higher with respect to other years. Even though dogs' owners are informed about the risk of pet infections by tick-borne pathogens and prophylaxis against ticks is often executed, E. canis and $A$. phagocytophilum are still present and infect the canine population in Central Italy.
\end{abstract}

Keywords: Ehrlichia canis; Anaplasma phagocytophilum; dogs; seroprevalence

\section{Introduction}

Ehrlichia canis and Anaplasma phagocytophilum are obligate intracellular Gram-negative bacteria belonging to the family Anaplasmataceae, order Rickettsiales [1]. Both pathogens are responsible for vector-borne infectious diseases of veterinary concern. E. canis mainly parasitizes the cells of the mononuclear phagocyte system and causes the canine monocytic ehrlichiosis (CME) characterized by clinical and hematological abnormalities such as fever, anorexia, vomiting, diarrhea, lymphadenopathy, petechial hemorrhages, bleeding tendency, anemia, and thrombocytopenia. CME after a subclinical or acute form can determine chronic infection that can persist for years [2].

E. canis usually infects dogs, but it is also able to cause infection in other canids and cats [3,4]. Moreover, a role as zoonotic agent has been supposed after the detection of this pathogen in clinical samples of human beings with clinical signs similar to those of CME [5].

A. phagocytophilum has tropism for granulocytes, mainly neutrophils and it is able to infect dogs, other canids, cats, horses, domestic and wild ruminants [6]. A. phagocytophilum-infected dogs may have clinical forms varying in severity degree. In general, $A$. phagocytophilum seems to cause less severe clinical signs than E. canis. Dogs may be asymptomatic or show fever, lethargy, reluctance to move, vomiting, diarrhoea, and nervous system dysfunction [7].

A. phagocytophilum is a zoonotic agent, responsible for the human granulocytic ehrlichiosis (HGE) or anaplasmosis (HGA) characterized by influenza-like symptoms that on rare occasions could have a fatal conclusion [8].

Both E. canis and A. phagocytophilum are transmitted by ticks during their blood meal. 
Rhipicephalus sanguineus sensu lato (s.1.), known as the brown dog-tick, is considered the main vector of E. canis as well as the only vector involved in the transmission of E. canis in Europe [2], even though Dermacentor variabilis, the American dog tick, has been shown to be a capable vector [9].

Ixodes ricinus ticks are considered the main vectors of A. phagocytophilum in Europe. Moreover, vector competence has been proven for other Ixodes species in other geographic areas. A. phagocytophilum DNA has been detected in Dermacentor spp., Haemaphysalis spp. and Amblyomma americanum that are supposed, but not proven, to be involved in the transmission of this microorganism [6].

A. phagocytophilum and E. canis have a worldwide distribution and previous investigations demonstrated their presence among canine population in Italy, too [10-18].

Data about the prevalence of these vector-borne pathogens are very variable in relation to the methods employed for their detection, geographic area, climatic conditions, presence of hematophagous vectors, environment in which dogs live, prophylaxis against arthropods. Moreover, available data are strictly related to animals' characteristics such as attitude (for instance pets or hunting dogs), free-roaming or owned, symptomatic or asymptomatic.

The aim of the present study was to update the information about the seroprevalence of E. canis and A. phagocytophilum infections among dogs living in Central Italy during a five-year period from 2013 to 2017.

\section{Results}

Among the 1026 examined dogs, 186 (18.12\%) were serologically positive for at least one pathogen and $14(1.36 \%)$ for both agents. More in detail, $166(16.18 \%)$ samples were positive for E. canis and $34(3.31 \%)$ for $A$. phagocytophilum. The number of dogs positive for both pathogens at the different antibody titers is reported in Table 1.

No statistically significant differences in the seroprevalence values related to gender were detected. Considering the animals' age, the highest percentage of E. canis-positive dogs was observed in dogs aged more than 10 years, whereas there were no significant differences in the prevalence for A. phagocytophilum (Table 2).

Mean seroprevalence values detected in 2014 and 2015 were statistically higher $\left(\chi^{2}\right.$ test, $\left.p<0.05\right)$ than those observed in the other years, as reported in Table 3.

Table 1. Number of dogs positive for Ehrlichia canis and Anaplasma phagocytophilum at the given antibody titer.

\begin{tabular}{cccccccc}
\hline \multicolumn{7}{c}{ Antibody Titers } \\
\hline & $1: 40$ & $1: 80$ & $1: 160$ & $1: 320$ & $1: 640$ & $1: 1280$ & Total \\
\hline Ehrlichia canis & 68 & 32 & 38 & 24 & 1 & 3 & 166 \\
Anaplasma phagocytophilum & 10 & 3 & 18 & 2 & 1 & - & 34 \\
\hline
\end{tabular}

Table 2. Serological results in relationship to gender and age of the canine study population.

\begin{tabular}{ccccc}
\hline Category & & $\begin{array}{c}\text { Study } \\
\text { Population }\end{array}$ & $\begin{array}{c}\text { E. canis-Positive Dogs } \\
\mathbf{( \% )}\end{array}$ & $\begin{array}{c}\text { A. phagocytophilum-Positive Dogs } \\
\mathbf{( \% )}\end{array}$ \\
\hline \multirow{2}{*}{ Gender } & Male & 588 & $95(16.15)$ & $18(3.06)$ \\
& Female & 438 & $71(16.21)$ & $16(3.65)$ \\
Age & $<1$ & 41 & $4(9.75)$ & $1(2.43)$ \\
& $1-5$ & 529 & $82(15.50)$ & $17(3.21)$ \\
& $6-10$ & 411 & $69(16.78)$ & $15(3.64)$ \\
& $>10$ & 45 & $11(24.44)$ & $1(2.22)$ \\
\hline
\end{tabular}


Table 3. Seroprevalence of Ehrlichia canis and Anaplasma phagocytophilum among tested dogs in relationship to the different years.

\begin{tabular}{cccc}
\hline Year & Number of Examined Dogs & $\begin{array}{c}\text { E. canis-Positive Dogs } \\
\mathbf{( \% )}\end{array}$ & $\begin{array}{c}\text { A.phagocytophilum-Positive Dogs } \\
\mathbf{( \% )}\end{array}$ \\
\hline 2013 & 197 & $26(13.20)$ & $5(2.53)$ \\
2014 & 225 & $63(28.0)$ & $14(6.22)$ \\
2015 & 196 & $40(20.40)$ & $10(5.10)$ \\
2016 & 174 & $16(9.19)$ & $3(1.72)$ \\
2017 & 234 & $21(8.97)$ & $2(0.85)$ \\
TOTAL & 1026 & $166(16.18)$ & $34(3.31)$ \\
\hline
\end{tabular}

\section{Discussion}

The mean seroprevalences detected for E. canis and A. phagcoytophilum show the presence of both tick-borne pathogens among the canine population living in Central Italy in the period from 2013 to 2017 , even though the seropositive reactions could be due not only to current infections, but also to previous exposure to the studied microorganisms.

E. canis was the most widespread tick-borne pathogen, with a mean seroprevalence of $16.18 \%$. No significant differences were detected in relation to gender of the tested dogs, whereas seroprevalence values were different in relation to the age; in particular, the highest percentage of seropositive reactions was found in the oldest animals. This result is in agreement with those of other surveys [19] and could be related to increasing vector exposure depending on animals' age and/or immunological status $[20,21]$.

Seroprevalence for A. phagocytophilum was significantly lower with a mean value of $3.31 \%$, and no statistically significant differences were observed in relation to age and gender of the analyzed dogs.

As has been suggested by other authors [19], the positive reactions to A. phagocytophilum could be due to cross-reactivity with Anaplasma platys, which has been previously found in the canine population in Italy [22,23].

Moreover, cross-reactions between antibodies against different Ehrlichia species can occur. In fact, antibodies against E. canis may cross-react with antigens of Ehrlichia ewingii, Ehrlichia chaffeensis, Ehrlichia ruminantium, Neorickettsia sennetsu (formerly Ehrlichia sennetu), and Neorickettsia risticii (formerly Ehrlichia risticii) [24,25]. However, the presence of these pathogens in Italy has not been documented, suggesting that they do not interfere in the serological diagnosis.

A low percentage of dogs $(1.36 \%)$ were seroreactive to both E. canis and A. phagocytophilum antigens. Some authors suggest that cross-reactions can occur between these agents, particularly when one of the two pathogens causes very high titers or when the follow up is prolonged [24]. In this study, dogs resulted positive to both pathogens with similar antibody titers, thus it cannot be excluded that animals had been exposed to both vector-borne microorganisms.

Limited data on seroprevalence of these tick-borne infections in Italian canine population are available. Moreover, it is difficult to compare seroprevalences detected in the present survey to values observed in other studies, because canine population and geographic area are very different.

However, some previous investigations found values in agreement with our results. A recent study performed among hunting dogs from Southern Italy found seroprevalences for E. canis and A. phagocytophilum of $7.6 \%$ and $4.4 \%$, respectively [18]. Another survey on candidate blood donors and free-roaming dogs from Northeastern Italy detected seroprevalences for A. phagocytophilum of $4.7 \%$ and $3.3 \%$, respectively. For E. canis this value was $0.9 \%$ in free-roaming dogs, while all candidate donors were negative [26].

A similar investigation carried out on dogs living in Central Italy during the period 2008-2012 found lower mean seroprevalence for E. canis $(7.07 \%)$, whereas seroprevalence for A. phagocytophilum was slightly higher $(4.68 \%)$ [27]. 
The present study found statistically significant differences among the seroprevalence values for both investigated pathogens in relation to the year of sampling had been collected. In fact, the highest seroprevalences for E. canis were observed during 2014 (28.0\%) and $2015(20.4 \%)$, whereas the values significantly decreased in the following years.

A similar behavior was observed with the seroprevalences for A. phagocytophilum, with the highest values detected in 2014 (6.22\%) and 2015 (5.1\%).

These results could be related to the climatic conditions, that are known to strongly influence the presence of ticks and other hematophagous arthropods in the environment and consequently the vector-borne pathogens' spreading.

The Italian Institute for Environmental Protection and Research (ISPRA) reports that 2014 and 2015 were very warm and rainy years in Italy. In more details, the average annual temperature in 2014 was $1.63{ }^{\circ} \mathrm{C}$ higher than the normal value in Central Italy. Moreover, 2014 total annual rainfall in Italy was overall higher than the climatic average of about $13 \%$ (12\% in Central Italy) [28].

Climatic data for 2015 by the ISPRA show that the 2015 average temperature value in Italy was the highest since 1961, slightly higher than that of in 2014. In detail, the average annual temperature was $1.70{ }^{\circ} \mathrm{C}$ higher in Central Italy. The annual rainfall in Italy was overall lower than the climatic average of about 13\%, but the climate in Central Italy was rainier than usual in March, August, and October [29].

The main vector of E. canis in Europe is R. sanguineus s.l., which is largely present in the Mediterranean basin. These ticks require a minimum environmental temperature of about $6{ }^{\circ} \mathrm{C}$ and a good degree of humidity. Rainy but not cold winters allow ticks to survive, although when environmental temperatures are too low, ticks are able to hibernate sheltered in the cracks of buildings and kennels [30].

I. ricinus ticks are widely distributed in most northern and central European areas and it is the main vector of $A$. phagocytophilum in Europe. This species is present in several parts of the Mediterranean region, including Italy. It can be mainly found in mixed and deciduous forests, open pastures, and other areas with high humidity [31]. Its wide distribution is also related to a broad host range, including many mammalian species and birds [32].

All animals tested in the present investigation were owned dogs with different attitude, but none of them was employed in hunting activity. Even though owners were not able to give information on tick infestation, it can be supposed that dogs had been in contact with $R$. sanguineus, I. ricinus, and probably other ticks in gardens, urban parks, and peri-urban recreational areas.

\section{Material and Methods}

\subsection{Animals}

From January 2013 to December 2017, peripheral whole-blood samples were collected from 1026 dogs. Animals were privately-owned dogs from different areas of Central Italy. No hunting dogs were included in the study. Moreover, animals were excluded if they were evaluated for suspected vector-borne diseases or if undergoing antibiotic treatment.

Once received, all samples were given an identification number and catalogued by data of sampling, animal age and gender. It was not possible to record data about tick infestation, because owners were not often able to give this information.

Whole-blood samples, drawn from the right or left cephalic vein, were centrifuged at $1500 \times \mathrm{g}$ for $15 \mathrm{~min}$. The sera were collected and immediately tested or stored at $-20^{\circ} \mathrm{C}$.

\section{Ethical statement}

The collection of blood samples was executed for other diagnostic purposes by collaborating veterinarians during clinical visits. No dogs were submitted to the blood collection only for this study. However, in all cases informed consent was obtained from the owners. 


\subsection{Serological Analyses}

The indirect immunofluorescence antibody test (IFAT) was executed on IFAT slides specific for Anaplasma phagocytophilum and Ehrlichia canis (Fuller Laboratories Fullerton, California, USA) antigens.

Blood sera were diluted 1:40 in phosphate-buffered saline (PBS, pH 7.2), considered as the cut-off dilution, and tested following the protocol previously reported [27]. Positive samples were two-fold serially diluted to determine the endpoint titre. Scores from 1 to 4 were assigned to the intensity of specific fluorescence and the antibody titre was defined as the major dilution with a 2 score.

\subsection{Statistical Analysis}

Statistical evaluation was carried out by the $\chi^{2}$ test to analyze the results of serological tests in relationship to gender and age of the examined dogs and to the years in which samples were collected. Values of $p<0.05$ were considered significant.

\section{Conclusions}

Even though dog owners are informed about the risk of pet infections by tick-borne pathogens and prophylaxis against ticks is often executed, E. canis and A. phagocytophilum were still found to be present in Central Italy. For this reason, veterinarians should consider these two pathogens in the case of suggestive clinical signs and in routine health status checks. Climatic conditions, as suggested by the obtained results, may influence the spreading of ticks and consequently the presence of tick-borne pathogens in animal populations. Prevention against dog tick infestation through acaracide treatments is the main tool to prevent infections, and a prompt diagnosis is necessary for appropriate therapy.

Moreover, constant surveillance of animal populations (mainly pets which share the same environment with their owners) in order to verify the spread of arthropod-borne pathogens is necessary from an One Health perspective.

Funding: This research received no external funding.

Conflicts of Interest: The authors declare no conflict of interest.

\section{References}

1. Dumler, J.S.; Barbet, A.F.; Bekker, C.P.; Dasch, G.A.; Palmer, G.H.; Ray, S.C.; Rikihisa, Y.; Rurangirwa, F.R. Reorganization of genera in the families Rickettsiaceae and Anaplasmataceae in the order Rickettsiales: unification of some species of Ehrlichia with Anaplasma, Cowdria with Ehrlichia with Neorickettsia, descriptions of six new species combination and designation of Ehrlichia equi and 'HGE agent' as subjective synonyms of Ehrlichia phagocytophila. Int. J. Syst. Evol. Microbiol. 2001, 51, 2145-2165. [CrossRef] [PubMed]

2. Sainz, Á.; Roura, X.; Miró, G.; Estrada-Peña, A.; Kohn, B.; Harrus, S.; Solano-Gallego, L. Guideline for veterinary practitioners on canine ehrlichiosis and anaplasmosis in Europe. Parasit. Vectors 2015, 8, 75. [CrossRef] [PubMed]

3. Maia, C.; Ramos, C.; Coimbra, M.; Bastos, F.; Martins, A.; Pinto, P.; Nunes, M.; Vieira, M.L.; Cardoso, L.; Campino, L. Bacterial and protozoal agents of feline vector-borne diseases in domestic and stray cats from southern Portugal. Parasit. Vectors 2014, 7, 115. [CrossRef] [PubMed]

4. Ebani, V.V.; Rocchigiani, G.; Nardoni, S.; Bertelloni, F.; Vasta, V.; Papini, R.A.; Verin, R.; Poli, A.; Mancianti, F. Molecular detection of tick-borne pathogens in wild red foxes (Vulpes vulpes) from Central Italy. Acta Trop. 2017, 172, 197-200. [CrossRef]

5. Perez, M.; Bodor, M.; Zhang, C.; Xiong, Q.; Rikihisa, Y. Human infection with Ehrlichia canis accompanied by clinical signs in Venezuela. Ann. N. Y. Acad. Sci. 2006, 1078, 110-117. [CrossRef] [PubMed]

6. Stuen, S.; Granquist, E.G.; Silaghi, C. Anaplasma phagocytophilum-A wide spread multi-host pathogen with highly adaptive strategies. Front. Cell. Infect. Microbiol. 2013, 3, 1-33. [CrossRef]

7. Greig, B.; Armstrong, P.J. Canine Granulocytotropic Anaplasmosis (A. phagocytophilum infection). In Infectious Diseases of Dog and Cat, 3rd ed.; Greene, C.E., Ed.; Saunders Elsevier: St. Louis, MO, USA, 2006; pp. 219-223, ISBN 978-1-4160-3600-5. 
8. Ismail, N.; Bloch, K.C.; McBride, J.W. Human ehrlichiosis and anaplasmosis. Clin. Lab. Med. 2010, 30, 261-292. [CrossRef]

9. Johnson, E.M.; Ewing, S.A.; Barker, R.W.; Fox, J.C.; Crow, D.W.; Kocan, K.M. Experimental transmission of Ehrlichia canis (Rickettsiales: Ehrlichieae) by Dermacentor variabilis (Acari: Ixodidae). Vet. Parasitol. 1998, 74, 277-288. [CrossRef]

10. Solano-Gallego, L.; Trotta, M.; Razia, L.; Furlanello, T.; Caldin, M. Molecular survey of Ehrlichia canis and Anaplasma phagocytophilum from blood of dogs in Italy. Ann. N. Y. Acad. Sci. 2006, 1078, 515-518. [CrossRef]

11. Corrain, R.; Di Francesco, A.; Bolognini, M.; Ciucci, P.; Baldelli, R.; Guberti, V. Serosurvey for CPV-2, distemper virus, ehrlichiosis and leishmaniosis in free-ranging dogs in Italy. Vet. Rec. 2007, 160, 91-92. [CrossRef]

12. Torina, A.; Vicente, J.; Alongi, A.; Scimeca, S.; Turlà, R.; Nicolsia, S.; Di Marco, V.; Caracappa, S.; de la Fuente, J. Observed prevalence of tick-borne pathogens in domestic animals in Sicily, Italy during 2003-2005. Zoonoses Public Health 2007, 54, 8-15. [CrossRef] [PubMed]

13. Trotta, M.; Fogliazza, A.; Furlanello, T.; Solano-Gallego, L. A molecular and serological study of exposure to tick-borne pathogens in sick dogs from Italy. Clin. Microbiol. Infect. 2009, 15, 62-63. [CrossRef] [PubMed]

14. Otranto, D.; Testini, G.; Dantas-Torres, F.; Latrofa, M.S.; Vissotto de Paiva Diniz, P.P.; de Caprariis, D.; Lia, R.P.; Mencke, N.; Stanneck, D.; Capelli, G.; et al. Diagnosis of canine vector-borne disease in young dogs: a longitudinal study. J. Clin. Microbiol. 2010, 48, 3316-3324. [CrossRef] [PubMed]

15. Pennisi, M.G.; Caprì, A.; Solano-Gallego, L.; Lombardo, G.; Torina, A.; Masucci, M. Prevalence of antibodies against Rickettsia conorii, Babesia canis, Ehrlichia canis and Anaplasma phagocytophilum antigens in dogs from the Stretto di Messina area (Italy). Ticks Tick Borne Dis. 2012, 3, 314-317. [CrossRef]

16. Ebani, V.V.; Bertelloni, F.; Turchi, B.; Cerri, D. Serological and molecular survey of Anaplasma phagocytophilum in Italian hunting dogs. Ann. Agric. Environ. Med. 2013, 20, 289-292.

17. Ebani, V.V.; Nardoni, S.; Fognani, G.; Mugnaini, L.; Bertelloni, F.; Rocchigiani, G.; Papini, R.A.; Stefani, F.; Mancianti, F. Molecular detection of vector-borne bacteria and protozoa in healthy hunting dogs from Central Italy. Asian Pac. J. Trop. Biomed. 2015, 5, 108-112. [CrossRef]

18. Piantedosi, D.; Neola, B.; D’Alessio, N.; Di Prisco, F.; Santoro, M.; Pacifico, L.; Sgroi, G.; Auletta, L.; Buch, J.; Chandrashekar, R.; et al. Seroprevalence and risk factors associated with Ehrlichia canis, Anaplasma spp., Borrelia burgdorferi sensu lato, and Dirofilaria immitis in hunting dogs from southern Italy. Parasitol. Res. 2017, 116, 2651-2660. [CrossRef]

19. Movilla, R.; García, C.; Siebert, S.; Roura, X. Countrywide serological evaluation of canine prevalence for Anaplasma spp., Borrelia burgdorferi (sensu lato), Dirofilaria immitis and Ehrlichia canis in Mexico. Parasit. Vectors 2016, 9, 421. [CrossRef]

20. Rodríguez-Viñas, R.I.; Albornoz, R.E.; Bolio, G.M. Ehrlichia canis in dogs in Yucatan, Mexico: seroprevalence, prevalence of infection and associated factors. Vet. Parasitol. 2005, 127, 75-79. [CrossRef]

21. Cardoso, L.; Mendão, C.; Madeira de Carvalho, L. Prevalence of Dirofilaria immitis, Ehrlichia canis, Borrelia burgdorferi sensu lato, Anaplasma spp. and Leishmania infantum in apparently healthy and CVBD-suspect dogs in Portugal-A national serological study. Parasit. Vectors 2012, 5, 62. [CrossRef]

22. De la Fuente, J.; Torina, A.; Naranjo, V.; Nicosia, S.; Alongi, A.; La Mantia, F.; Kocan, K.M. Molecular characterization of Anaplasma platys strains from dogs in Sicily, Italy. BMC Vet. Res. 2006, 2, 24. [CrossRef] [PubMed]

23. Antognoni, M.T.; Veronesi, F.; Morganti, G.; Mangili, V.; Fruganti, G.; Miglio, A. Natural infection of Anaplasma platys in dogs from Umbria region (Central Italy). Vet. Ital. 2014, 50, 49-56. [PubMed]

24. Waner, T.; Harrus, S.; Jongejan, F.; Bark, H.; Keysary, A.; Cornelissen, A.W. Significance of serological testing for ehrlichial diseases in dogs with special emphasis on the diagnosis of canine monocytic ehrlichiosis caused by Ehrlichia canis. Vet. Parasitol. 2001, 95, 1-15. [CrossRef]

25. Harrus, S.; Waner, T. Diagnosis of canine monocytropic ehrlichiosis (Ehrlichia canis): an overview. Vet. J. 2011, 187, 292-296. [CrossRef] [PubMed]

26. Vascellari, M.; Ravagnan, S.; Carminato, A.; Cazzin, S.; Carli, E.; Da Rold, G.; Lucchese, L.; Natale, A.; Otranto, D.; Capelli, G. Exposure to vector-borne pathogens in candidate blood donor and free-roaming dogs of northeast Italy. Parasit. Vectors 2016, 9, 369. [CrossRef] [PubMed] 
27. Ebani, V.V.; Bertelloni, F.; Torracca, B.; Cerri, D. Serological survey of Borrelia burgdorferi sensu lato, Anaplasma phagocytophilum and Ehrlichia canis infections in rural and urban dogs in Central Italy. Ann. Agric. Environ. Med. 2014, 21, 671-675. [CrossRef] [PubMed]

28. Desiato, F.; Fioravanti, G.; Fraschetti, P.; Perconti, W.; Piervitali, E.; Pavan, V. Gli Indicatori del Clima in Italia nel 2014. Anno X. ISPRA. Stato dell'Ambiente 57/2015. ISBN 978-88-448-0722-1. Available online: http:/ / www.isprambiente.gov.it/ files/pubblicazioni/statoambiente/SA_57_15_Indicatori_clima_ 2014.pdf (accessed on 31 November 2018).

29. Desiato, F.; Fioravanti, G.; Fraschetti, P.; Perconti, W.; Piervitali, E.; Pavan, V. Gli Indicatori del Clima in Italia nel 2015. Anno XI ISPRA. Stato dell'Ambiente 65/2016. ISBN 978-88-448-0779-5. Available online: http: / / www.isprambiente.gov.it/ files/pubblicazioni/statoambiente/Rapporto_2015_revfinale197.pdf (accessed on 31 November 2018).

30. Gray, J.; Dantas-Torres, F.; Estrada-Pena, A.; Levin, M. Systematics and ecology of the brown dog tick, Rhipicephalus sanguineus. Ticks Tick Borne Dis. 2013, 4, 171-180. [CrossRef] [PubMed]

31. Medlock, J.M.; Hansford, K.M.; Bormane, A.; Derdakova, M.; Estrada-Pena, A.; George, J.C.; Golovljova, I.; Jaenson, T.G.T.; Jensen, J.K.; Jensen, P.M.; et al. Driving forces for changes in geographical distribution of Ixodes ricinus ticks in Europe. Parasit. Vectors 2013, 6, 1. [CrossRef]

32. Kocianová, E.; Rusñáková Taragel'ová, V.; Haruštiaková, D.; Špitalská, E. Seasonal infestation of birds with immature stages of Ixodes ricinus and Ixodes arboricola. Ticks Tick-borne Dis. 2017, 8, 423-431. [CrossRef]

(C) 2019 by the author. Licensee MDPI, Basel, Switzerland. This article is an open access article distributed under the terms and conditions of the Creative Commons Attribution (CC BY) license (http://creativecommons.org/licenses/by/4.0/). 